\title{
Characterization of Volume F trash from the three FY11 STS missions: Trash weights and categorization and microbial characterization
}

\author{
Richard F. Strayer ${ }^{1}$, Mary E. Hummerick', Jeffery T. Richards ${ }^{1}$, LaShelle E. McCoy ${ }^{1}$, Michael S. Roberts ${ }^{1}$ \\ Sustainable Systems Research - Team Qinetiq-NA (ESC-24), Kennedy Space Center, FL, 32899
}

Raymond M. Wheeler ${ }^{2}$

Surface Systems Division (NE-S), Kennedy Space Center, FL, 32899

\begin{abstract}
This research project provided microbial characterization support to the Waste Management Systems (WMS) element of NASA's Life Support and Habitation Systems (LSHS) program. Conventional microbiological methods were used to detect and enumerate microorganisms in space-generated solid wastes, i.e., STS Volume F Compartment trash returned from orbit and missions to ISS. Crew generated STS trash was characterized for three shuttle missions: STS 133, STS 134, and STS 135. The waste was catalogued into logical categories, weighed, and the water content determined. Results for FY11 STS missions showed more variability than for the FY10 study of STS 129-132 and indicated some waste was probably not included in what was returned to KSC on the STS. Microbial characterization of wastes from each mission and each category determined the presence of high numbers of microbes in food waste and food packaging, in drink pouches, and in personal hygiene wastes. A number of bacteria and fungi were identified, including known pathogens and some likely opportunistic pathogens that could cause problems if these wastes were exposed to an immune compromised crew.
\end{abstract}

\footnotetext{
Nomenclature

APC = Aerobic plate count or the number of bacterial colonies counted on agar plates incubated aerobically times a dilution factor and calculated per unit of sample.

AnPC = Anaerobic plate count or the number of bacterial colonies counted on agar plates incubated anaerobically times a dilution factor and calculated per unit of sample.

$\mathrm{CFU}=$ Colony forming units

EPC = Estimated plate count. Based on plates with a "to numerous to count" result.

HT APC = Heat treated Aerobic plate count or the number of bacterial colonies counted on agar plates incubated aerobically times a dilution factor and calculated per unit of sample from sample diluent that is subjected to heat treatment of $85^{\circ} \mathrm{C}$ for 15 minutes thereby selecting for heat resistant spore forming bacteria.

HT AnPC = Heat treated Anaerobic plate count or the number of bacterial colonies counted on agar plates incubated anaerobically times a dilution factor and calculated per unit of sample from sample diluent that is subjected to heat treatment of $85^{\circ} \mathrm{C}$ for 15 minutes thereby selecting for heat resistant spore forming bacteria that grow anaerobically.

$\mathrm{Y}+\mathrm{M}=$ Yeast and mold colonies counted on inhibitory mold agar.

WMS $=$ Waste Management Systems.
}

\footnotetext{
${ }^{1}$ Research Scientist, Sustainable Systems Research, Mail Code ESC-24, Kennedy Space Center, FL 32899.

${ }^{2}$ Senior Scientist, Surface Systems Division, Mail Code NE-S, Kennedy Space Center, FL 32899.
} 


\section{Introduction}

AUMBER of solid waste treatment technologies are under development by the Waste Management Systems (WMS) element within the Life Support and Habitation Systems (LSHS) program. The goals of these treatments are to (1) reduce the volume of the waste because storage space is very limited on space vehicles, (2) remove and recover water because many wastes contain water and easily biodegraded organic compounds from food wastes and crew feces, (3) stabilize and make wastes safe for the crew and harmless to the environment, (4) contain waste to isolate it from the crew and the rest of the world, and dispose of the contained waste, and (5) process the waste for reuse of resources within the stored waste.

Untreated or unprocessed solid wastes / trash components contain organic compounds that are easily biodegraded. As the action of microbes on these labile solid waste components is largely responsible for both microbial proliferation. Two studies at KSC in FY07 and FY08, respectively, had examined the microbial characterization of food wastes in simulated space mission trash, i.e., for a Lunar Base.

In the KSC-WMS FY07 project ${ }^{1}$, food wastes were inoculated with material from volunteer / donor mouth scrubbing. Volunteer body wipes, in lieu of a shower, disinfectant and wet wipes of facility urinals and commodes, and dry wipes of laboratory tabletop surfaces were also added to the simulated waste after placing the wipes into a zip lock bags, which were then sealed. The likely reasons that pathogens were not detected are: volunteer mouths did not contain the particular pathogens we were trying to detect; these microbes were below detection levels; wipes were contained in plastic bags, which were not opened during incubation or sampling. The most likely reason is that the inocula did not contain pathogens.

In the FY08 study, selected microorganisms, including pathogens, were added as challenge microbes into simulated food trash compartment waste. The list included those microbes that could be introduced as crosscontamination inocula from other solid waste sources: Escherichia coli and Salmonella enterica serovar typhimurium (enteric gram negative bacteria), Staphylococcus aureus (gram positive bacterium), Aspergillus niger (a common mold), Pseudomonas aeruginosa (gram negative bacterium), and Bacillus pumilus SAFR-032, a gram positive spore-forming bacterium which served as a positive control. The methods used to detect these specific microbes included conventional cultivation-based microbiological methods and the molecular biology method known as quantitative polymerase chain reaction, or qPCR. Fate of these microbes was examined for control wastes that had not received the added challenge microbes but had been inoculated with normal microflora from donors and food waste that had received both inocula. Limitations are that other pathogenic microbes, not examined here, might also be able to grow in food wastes. Major FY08 findings - $\mathrm{O}_{2}$ levels were easily maintained above the target of $1 \%$ in the gas space of each bag by the gas control and monitoring system. Both cultivation-based and molecular-based (e.g. qPCR-based) counts strongly indicated that added challenge microbes, including pathogenic bacteria, could grow and proliferate during simulated spacecraft storage of food trash compartment wastes. Some added microbes, i.e., Staphylococcus aureus, Escherchia coli, and Pseudomonas aeruginosa increased between 3 and 5 orders of magnitude over the first 3 days of storage. After six weeks of simulated trash storage, most added pathogens were still present at high levels, with little die-off noticed. Results from this task project demonstrate that potential problems regarding pathogens as cross-contaminants from other sources including other waste streams could develop during storage of space mission solid wastes. If storage of these wastes is the only 'treatment' option, then, to prevent crew exposure to dangerous levels of cross-contaminating pathogens, we recommended that food wastes be placed immediately into storage and the containers immediately sealed. We believe that a better treatment option would be to limit microbial growth through immediate dehydration of food, or other, wastes or immediate sterilization of these wastes. The results reported here can be used to determine requirements and criteria for NASA Waste Management Systems. These methods and resulting data will provide a basis for testing technologies for the ability to limit contaminant survival, growth and proliferation.

For FY10, KSC conducted a characterization of space-mission generated wet waste, i.e., trash. The trash material was 'Volume F' trash and other trash, in large zip-lock bags, that accompanied the Volume F Compartment wet waste (trash) from four recent STS missions, 129, 130, 131, and 132. Determinations were made for trash content, weight and water content ${ }^{2}$, and the microbial characterization of this trash ${ }^{3}$. These results were presented at $41^{\text {st }}$ ICES last year.

NASA can use the results to determine requirements and criteria for Waste Management Systems on future missions.

Objective: Characterize the microbial loading and risks of STS Volume F Compartment trash. 


\section{Materials and Methods}

Voume $\mathrm{F}$ wet trash and other large ziplock plastic bags, which also contained trash items, are generated on each STS mission, whether to the International Space Station (ISS) or not.

\section{A. Sequence of sampling events for each shuttle landing at KSC}

Upon notification by shuttle personnel, usually within 48 hours of landing, the Volume $F$ trash waste was picked up from landing support personnel. Trash was stored at room temperature, between 1 and 3 days, before it could be processed and characterized. Processing and characterization, including microbial characterization from sample acquisition to dilutions to inoculation of enumeration media, usually took 2 to 3 work days.

First, total wet weight was determined of the entire Volume $\mathrm{F}$ trash and any accompanying large zip-lock bags of trash. The Volume $\mathrm{F}$ trash bag and accompanying bags were next opened and the contents were cataloged and photographed. The contents were smaller plastic liner bags, termed 'footballs' by former STS crews, that had been closed by wrapping them with duct tape. Footballs that contained what looked like food trash, drink pouches, or personal hygiene items were aseptically cut open and the contents were sorted and placed into categories. Footballs that obviously contained MAGs or elbow packs, i.e., toilet wipes, were not opened at this time, but placed into these categories. Next, the total wet weight of each category was determined and subsamples were taken, aseptically for microbiological analyses and some for dry weight determinations $\left(70{ }^{\circ} \mathrm{C}\right.$ until dry, usually overnight). During the physical categorization and opening of footballs, outer plastic bags and duct tape were placed into the plastic and packaging category to determine a total weight of this category.

\section{B. Microbiological analyses}

1. Sample preparation.

Waste items that were to be sampled for microbiological analyses were placed into sterile gallon ziplock bags and $1.5 \mathrm{~L}$ of sterile deionized water was added. The bag contents and water were mixed / shaken by hand for 2 minutes $\left(10^{-2}\right.$ dilution $)$ and a 10 -fold dilution series was prepared from the trash-water mixture. These dilutions were then used to obtain: acridine orange direct counts, numbers of cultivatable total aerobic and anaerobic bacteria, cultivatable gram positive spore forming bacteria, selected cultivatable bacteria (Staphylococcus aureus, Coliforms and Escherichia coli); and cultivatable fungi (yeast and molds).

2. Microbial Load via Acridine Orange Direct Count (AODC).

A portion of all samples for microbiological analyses were fixed with $0.2 \mu \mathrm{m}$-filtered $37 \%$ formalin to a final formalin concentration of $2 \%$. These formalin-fixed samples were usually processed within two hours after fixation. However, occasionally they had to be stored at $4^{\circ} \mathrm{C}$ for up to two weeks until filtered for enumeration. Formalinfixed samples were sonicated, diluted into $0.2 \mu \mathrm{m}$-filtered de-ionized water, stained with Acridine Orange, and filtered onto $25-\mathrm{mm}$ (diameter), $0.2 \mu \mathrm{m}$ (pore size) black polycarbonate filters for enumeration. Some samples required serial dilution to $10^{-1}-10^{-3}$ for accurate enumeratin. Direct counts of filtered samples were determined using a Zeiss Epi-Fluorescent Axioskop microscope at $1000 \mathrm{x}$ magnification. Microscope software used for counting and observing cells was DP Manager, DP Controller, and Image-Pro Express 6.3.

3. Cultivatable total aerobic and anaerobic bacteria.

A dilution series of blended, trash-DI samples was plated onto R2A agar which was incubated aerobically and anaerobically (AnaeroPack System, Mitsubishi Gas Chemical Co. Tokyo, Japan) at $30^{\circ} \mathrm{C}$ for 48 hours before enumeration.

4. Cultivatable gram positive spore forming bacteria.

Counts of gram positive spore forming bacteria were determined after heat shock treatment $\left(80{ }^{\circ} \mathrm{C}\right.$ for 15 minutes) of the blended, trash-DI samples and this treated dilution was plated onto R2A agar (incubated aerobically and anaerobically) at $30^{\circ} \mathrm{C}$ for 48 hours before enumeration.

\section{Selected cultivatable bacteria.}

Samples were screened for potential pathogens by plating blended samples on selective media, S. aureus was isolated on Mannitol Salt agar(MSA) (Difco) and Staph Express petri film (3M) and E. coli and coliforms on E. coli/ coliform petrifilm (3M) ..

\section{Cultivatable fungi.}

Yeast and fungal counts that occurred in the blended trash-DI samples were obtained using Inhibitory Mold Agar (IMA)(Difco) .

\section{Bacterial and Fungal isolate identification}

All colonies that grew on any of the media where further isolated and identified by either the Biolog micro ID system by the inoculation of pure cultures into GEN III plates (bacteria identification), or the plates specific for 
yeast and filamentous fungi per manufacturers instructions. For isolates that were not identified by the Biolog, additional ID tests were run using the MicroSeq ${ }^{\circledR}$ D2 LSU rDNA Fungal Sequencing and the MicroSeq® $50016 \mathrm{~s}$ rDNA Bacterial Sequencing identification kits (ABI) following the manufacturer's recommended protocol. For these IDs, DNA was isolated from cultivated microbes using the PrepMan ${ }^{\mathrm{TM}}$ Ultra Sample Preparation Reagent (ABI) and diluted 1:100. The PCR Module from the kit used approximately $25 \mathrm{ng}$ of genomic DNA on the BioRad C1000 thermocycler. The PCR thermocycling conditions were: $95^{\circ} \mathrm{C}$ for 10 minutes, 30 cycles of $95^{\circ} \mathrm{C}$ for 30 seconds, $60^{\circ} \mathrm{C}$ for 30 seconds, $72^{\circ} \mathrm{C}$ for 45 seconds, and finished with $72^{\circ} \mathrm{C}$ for 10 minutes. PCR product was run on a SYBR Safe (Invitrogen) 2\% agarose gel (Sigma) with the Benchtop pGEM® DNA markers (Promega) and visualized for quality and size. $5 \mu \mathrm{L}$ of the PCR product was then purified with $2 \mu \mathrm{L}$ of ExoSAP-IT® (USB) in duplicate. The $7 \mu \mathrm{L}$ of purified sample was then processed through the sequencing module of the kit. The cycle sequencing thermocycling conditions were: 25 cycles of $96^{\circ} \mathrm{C}$ for 10 seconds, $50^{\circ} \mathrm{C}$ for 5 seconds, and $60^{\circ} \mathrm{C}$ for 4 minutes. The excess dye terminators and primers were removed the cycle sequencing reaction with the DyeEx $2.0 \mathrm{Spin} \mathrm{Kit}$ (Qiagen). $7.5 \mu \mathrm{L}$ of $\mathrm{Hi}-\mathrm{Di}^{\mathrm{TM}}$ Formamide $(\mathrm{ABI})$ was loaded with $7.5 \mu \mathrm{L}$ of the purified product on the $\mathrm{ABI} 3130$ Genetic Analyzer. Results were analyzed with the MicroSeq Analysis Software (ABI).

\section{Results and Discussion}

\section{A. Separation, cataloging, and sampling of trash returned on STS 133, STS 134, and STS 135}

As noted by Kish, et al. ${ }^{4}$ and ${ }^{5}$ wet trash waste storage aboard the orbiter is in the Shuttle middeck area and is called the Volume F compartment. The wet trash includes mealtime wastes such as leftover food and drink and the associated food packaging, personal hygiene articles, toilet wipes (termed "elbow packs" because of their shape), and Maximum Absorbancy Garment (MAG) worn by the crew during launch and extravehicular activities (EVA). For FY11, the Volume F trash from the three STS missions were analyzed for this report. The mission specifics are shown in Table 1. The number of EVAs should influence the weight of the personal hygiene category as there are two crew members per EVA, thus two MAGs per EVA.

8. Comparison of total weights of STS trash by mission

Table 2 is a summary of the wet weight of trash by FY11 STS mission. Because mission duration and crew size

\begin{tabular}{ccccc}
\hline \multicolumn{4}{c}{ Table 1. Mission information for Shuttle Volume F trash characterized in this study. } \\
\hline Shuttle Mission & Crew Size & Launch Date & Landing Date & Mission duration, No.of EVAs \\
STS 133 & 6 & 24-Feb-11 & 09-Mar-11 & 13 days, 2 spacewalks \\
STS 134 & 6 & 16-May-11 & 01-Jun-11 & 16 days, 4 spacewalks \\
STS 135 & 4 & 08-Jul-11 & 21-Jul-11 & 13 days, 1 spacewalk by ISS crew \\
\hline
\end{tabular}

should have an effect on the amount of trash generated, the right column shows the trash production 'rate', in mass per crew member per day. On this basis, STS 133 had the most trash, $40 \mathrm{~kg}$. In comparison, of the four STS missions that were characterized at KSC as part of the FY10 project $^{1}$ the mission with the lowest amount of trash was $40 \mathrm{~kg}$ and the maximum was $58 \mathrm{~kg}$. The average production rates for wet trash for the three FY11 missions were $0.36 \pm 0.16 \mathrm{~kg} \mathrm{crew}^{-1}$ day $^{-1}$. This production weight is a way of normalizing data for comparison between

\begin{tabular}{|c|c|c|c|c|}
\hline \multicolumn{5}{|c|}{ Table 2. Summary of STS trash weight by mission. } \\
\hline $\begin{array}{c}\text { STS } \\
\text { mission }\end{array}$ & $\begin{array}{l}\text { Crew } \\
\text { size }\end{array}$ & $\begin{array}{l}\text { Mission } \\
\text { duration }\end{array}$ & $\begin{array}{c}\text { Total trash } \\
\text { weight }\end{array}$ & $\begin{array}{c}\text { Trash production } \\
\text { 'rates' }\end{array}$ \\
\hline & & days & $\mathrm{kg}_{\text {wet }}$ & $\mathrm{kg}_{\text {wet }}$ crew $^{-1} \mathrm{~d}^{-1}$ \\
\hline 133 & 6 & 13 & 40.0 & 0.513 \\
\hline 134 & 6 & 16 & 19.2 & 0.199 \\
\hline 135 & 4 & 13 & 19.4 & 0.373 \\
\hline & & \multirow{2}{*}{\multicolumn{2}{|c|}{$\begin{array}{c}\text { Average, } \mathrm{n}=3 \\
\text { Standard deviation }\end{array}$}} & 0.362 \\
\hline & & & & 0.157 \\
\hline
\end{tabular}

4

American Institute of Aeronautics and Astronautics 
missions. For FY10 this average, at $0.60 \pm 0.09 \mathrm{~kg} \mathrm{crew}^{-1}$ day ${ }^{-1}$, was nearly 1.7 times greater, with less variability, than FY11 trash. Several possible reasons for this include: Variable amounts of trash were left by the crew on ISS trash collection areas, rather than returned on STS; and trash from both STS 134 and 135 seemed to be missing some key components / categories (discussed later when details of trash categories are presented). In addition to these possibilities for explaining missing trash, especially on STS 134 and 135, at KSC the impact of contractor personnel layoffs at the end of the shuttle program during the last two missions may have had an impact on us receiving all of the trash that was returned on the shuttle. Particularly for STS 135, we did not receive any of the extra, additional zip lock bags that we labeled Bags $\mathrm{A}, \mathrm{B}$ or $\mathrm{C}$, the number and labeling depending on how many we received from post-landing, shuttle contractor personnel.

\section{Determination of weight distribution STS trash by category.}

As for the KSC FY10 project ${ }^{1}$, the FY11 categories that were assigned to waste items during the inventory of trash contents were: (1) Personal Hygiene - which consisted of towels, cleaning supplies, used and unused MAGs, Elbow packs, and wipes; (2) Drink items - which consisted of drink pouches and containers of breakfast drinks, water, fruit drinks, etc.; (3) Food waste including packaging; (4) Office waste and supplies - paper, gloves, tissues; (5) Plastic film - the outer bags of Volume F bag, Bags A, B, and C, and the outer covering of 'footballs' which consisted of plastic bags and duct tape, and zip-lock style bags. Unlike FY10 ${ }^{1}$, no trash items were placed in the (6) Miscellaneous category.

Table 3 gives a summary of the wet weight distribution by waste category. Personal hygiene wastes made up the largest category of waste at $56 \%$ of the total trash, followed by food wastes including packaging (18\%) and drink items/containers $(\sim 11 \%)$. Also shown, for comparison, in Table 3 in the two columns on the right are percentages

Table 3. Weight distribution in STS trash by category. Sum of the three STS missions in this
FY11 study. Comparison with percent of trash for 4 missions in the FY10 study and percent for
all 7 missions fo FY10 \& FY11
\begin{tabular}{r|cc|c|c}
\hline \multicolumn{2}{|c|}{ FY11 } & FY 10 & Both years \\
\hline Waste category & $\begin{array}{c}\text { Total wet } \\
\text { weight (kg) }\end{array}$ & $\begin{array}{c}\text { Percent of } \\
\text { FY11 trash }\end{array}$ & $\begin{array}{c}\text { Percent of } \\
\text { FY10 trash }\end{array}$ & $\begin{array}{c}\text { Percent of } \\
\text { total trash }\end{array}$ \\
\hline Personal Hygiene & 31.9 & $56.1 \%$ & $49.5 \%$ & $51.2 \%$ \\
Drink items & 6.0 & $10.5 \%$ & $15.8 \%$ & $14.5 \%$ \\
Food, incl packaging & 10.3 & $18.1 \%$ & $21.9 \%$ & $21.1 \%$ \\
Office waste & 1.7 & $3.1 \%$ & $1.6 \%$ & 2.0 \\
Plastic film & 6.7 & $11.7 \%$ & $10.8 \%$ & $11.0 \%$ \\
\hline
\end{tabular}

for the 4 missions we categorized in FY10 ${ }^{1}$ and the percentages for all 7 missions for both FY10 and FY11. The conclusions remain the same when looking at all of the data, i.e., personal hygiene wastes made up the largest category, followed by food wastes, then by drink items. Differences between FY11 and FY10 percentages might be due to the aforementioned assumed missing trash items for FY11.

Table 4 (a, b, and c) shows the contents of individual bags of Shuttle trash that were received by KSC and included more than the Volume $\mathrm{F}$ trash compartment. Additional bags of trash were labeled when received as Bag A, Bag B, etc. to keep track of the waste source(s). The number of these bags for each mission were: two - Bag A and Bag B - for STS 133 (Table 4a), one - Bag A - for STS 134 (Table 4b), and none for STS 135 (Table 4c). As Table 4 shows, the contents of these bags varied, but some trends were noted. Most of the drink pouches were in the additional Bags A and B, 89\% for STS 133 and $60 \%$ for STS 134 . These numbers compare with those for FY 10. However, there were hardly any drink containers for STS 135 wastes (Volume F compartment trash only). This and the low total fresh weight of the waste (Table 2) are the primary reasons we believe we did not receive all of the waste for this mission. 


\begin{tabular}{|c|c|c|c|c|c|}
\hline Source & Waste Category & Wet weight, $g$ & $\%$ moisture & Calculated water, $g$ & $\begin{array}{l}\text { Trash production } \\
\text { rate, } \mathrm{g} \mathrm{CD}^{-1}\end{array}$ \\
\hline \multirow{6}{*}{ Bag A } & Personal Hygiene & 1,540 & $31.5 \%$ & 485 & 19.4 \\
\hline & Drink items & 2,060 & $27.5 \%$ & 567 & 26.4 \\
\hline & Food, incl packaging & 160 & $2.0 \%$ & 3 & 2.0 \\
\hline & Office waste & 320 & & & 4.1 \\
\hline & Plastic film & 1,180 & & & 15.1 \\
\hline & Subtotal & 5,260 & & 1,056 & 67.4 \\
\hline \multirow{6}{*}{ Bag B } & Personal Hygiene & 720 & $29.7 \%$ & 214 & 9.2 \\
\hline & Drink items & 1,880 & $33.0 \%$ & 620 & 24.1 \\
\hline & Food, incl packaging & 740 & $4.3 \%$ & 32 & 9.5 \\
\hline & Office waste & 641 & & & 8.2 \\
\hline & Plastic film & 1,680 & & & 21.54 \\
\hline & Subtotal & 5,661 & & 866 & 72.6 \\
\hline \multirow{6}{*}{ Volume F } & Personal Hygiene & 15,520 & & & 199.0 \\
\hline & Drink items & 500 & $38.6 \%$ & 193 & 6.4 \\
\hline & Food, incl packaging & 3,020 & $42.6 \%$ & 1,285 & 38.7 \\
\hline & Office waste & - & & & 0 \\
\hline & Plastic film & 700 & & & 9.0 \\
\hline & Subtotal & 19,740 & & 1,478 & 253.1 \\
\hline & Grand total & 30,661 & & 3,399 & 393.1 \\
\hline & Shipped to ARC & 9,320 & & & \\
\hline
\end{tabular}

Most of the food waste items were in the Volume F trash - 77\% for STS 133 and $74 \%$ for STS 134 . This compares with an average of $86 \%$ of food waste items in the Volume F trash for the 4 missions in FY 10 . Wastes in the personal hygiene category were mostly found in the Volume F trash for STS 133 and $134-87 \%$ and $84 \%$ which again compares well with results for FY 10 trash with $88 \%, 97 \%$ and $80 \%$-- except for STS 130 where most of the personal hygiene wastes were in Bags A, B, and C.

Note that the water content of trash for STS 133 is missing the \% moisture for the personal hygiene waste of the Volume $\mathrm{F}$ trash. The dry weight data for this was, unfortunately, lost. Because the personal hygiene waste runs about $65 \%$ water and because the total wet weight of this was $15 \mathrm{~kg}$, the water distribution that should have been in Table 2 and 3 was not included. Water content for all other waste categories in STS 133 and 134 wastes are given individually in Table 4 ( $a$ and $b$ ). Because of the low amount of waste received for STS 135 and the missing drink containers for this mission, dry weights were taken for only the food waste items returned on this mission.

These data also show the importance of dividing wastes into categories before taking samples for microbial characterization or for further treatment for water recovery and/or waste sanitization or sterilization. 


\begin{tabular}{|c|c|c|c|c|c|}
\hline Source & Waste Category & Wet weight, $g$ & $\begin{array}{c}\% \\
\text { moisture }\end{array}$ & $\begin{array}{c}\text { Calculated } \\
\text { water, g }\end{array}$ & $\begin{array}{l}\text { Trash production } \\
\text { rate, } \mathrm{g} \mathrm{CD}^{-1}\end{array}$ \\
\hline \multirow[t]{7}{*}{ Bag "A" } & Personal Hygiene & 860 & $6.3 \%$ & 54 & 9.0 \\
\hline & Drink items & 820 & $9.0 \%$ & 74 & 8.5 \\
\hline & Food, including packaging & 600 & $1.7 \%$ & 10 & 6.3 \\
\hline & Office waste & 720 & & - & 7.5 \\
\hline & Plastic film & 1,360 & & - & 14.2 \\
\hline & Misc. & & & - & \\
\hline & Subtotal & 4,360 & & 139 & 45.4 \\
\hline \multirow[t]{8}{*}{ Volume F } & Personal Hygiene & 4,860 & $64.4 \%$ & 3,129 & 50.6 \\
\hline & Drink items & 554 & $22.9 \%$ & 127 & 5.8 \\
\hline & Food, including packaging & 1,736 & $21.6 \%$ & 376 & 18.1 \\
\hline & Office waste & 60 & $0.0 \%$ & - & 0.6 \\
\hline & Plastic film & 1160 & $0.0 \%$ & - & 12.1 \\
\hline & Subtotal & 8,370 & $43.4 \%$ & 3,622 & \\
\hline & Grand total & 12,730 & $29.6 \%$ & 3,711 & 87.2 \\
\hline & Shipped to ARC & 6,420 & & & \\
\hline
\end{tabular}

\begin{tabular}{|c|c|c|c|c|c|}
\hline Source & Waste Category & Wet weight, g & $\begin{array}{c}\% \\
\text { moisture } \\
\end{array}$ & $\begin{array}{c}\text { Calculated water, } \\
\text { g }\end{array}$ & $\begin{array}{l}\text { Trash production } \\
\text { rate, } \mathrm{g} \mathrm{CD}^{-1}\end{array}$ \\
\hline \multirow{6}{*}{ Volume F } & Personal Hygiene & 8,401 & \multirow{5}{*}{29.9} & \multirow{6}{*}{1,296} & 161.6 \\
\hline & Drink items & 173 & & & 3.3 \\
\hline & Food, incl packaging & 4,335 & & & 83.4 \\
\hline & Office waste & 0 & & & 0 \\
\hline & Plastic film & 577 & & & 11.1 \\
\hline & Subtotal & 13,486 & $9.6 \%$ & & 259.3 \\
\hline & $\begin{array}{l}\text { Grand total } \\
\text { Shinned to ARC }\end{array}$ & $\begin{array}{l}13,486 \\
59136\end{array}$ & 9.6 & 1,296 & 259.3 \\
\hline
\end{tabular}

10. Summary charts for both FY10 and FY11 STS missions by waste/trash category.

Although the FY10 results for four STS missions were published last year, the opportunity to summarize the trash results from all seven STS missions in FY10 and FY11 could not be ignored. Figure 1 shows a graph of trash production rates as $\mathrm{g}_{\text {wet weight }} \mathrm{CD}^{-1}$ with a stacked bar for each mission. $\mathrm{CD}$ stands for crew day and is the number of crew members on the STS mission times the duration of the mission in days. The data that is stacked into each bar is the trash production rate for each category, including the waste (approx. 30\% of that mission) that was shipped to $\mathrm{ARC}$ and, thus, not categorized because they were not opened and catalogued. This authentic space generated trash will be used by them during testing of the Heat Melt Compactor ${ }^{6}$. The trash production rate over the course of the two year study shows variation between missions with for the first two missions having the highest trash production rate, the next three a bit lower, but consistent, and the last two the lowest.

Figure 2 shows the same data used to make up the stacks, but with each figure panel showing trash production rates $\left(\mathrm{g}_{\text {wet weight }} \mathrm{CD}^{-1}\right)$ for one of the five categories: personal hygiene, drink containers, food waste and packaging, office waste, and plastic film. The trash sent to ARC is not shown here because it was an arbitrary number at $\sim 30 \%$ that was set by us and thus is not a meaningful category per se. 


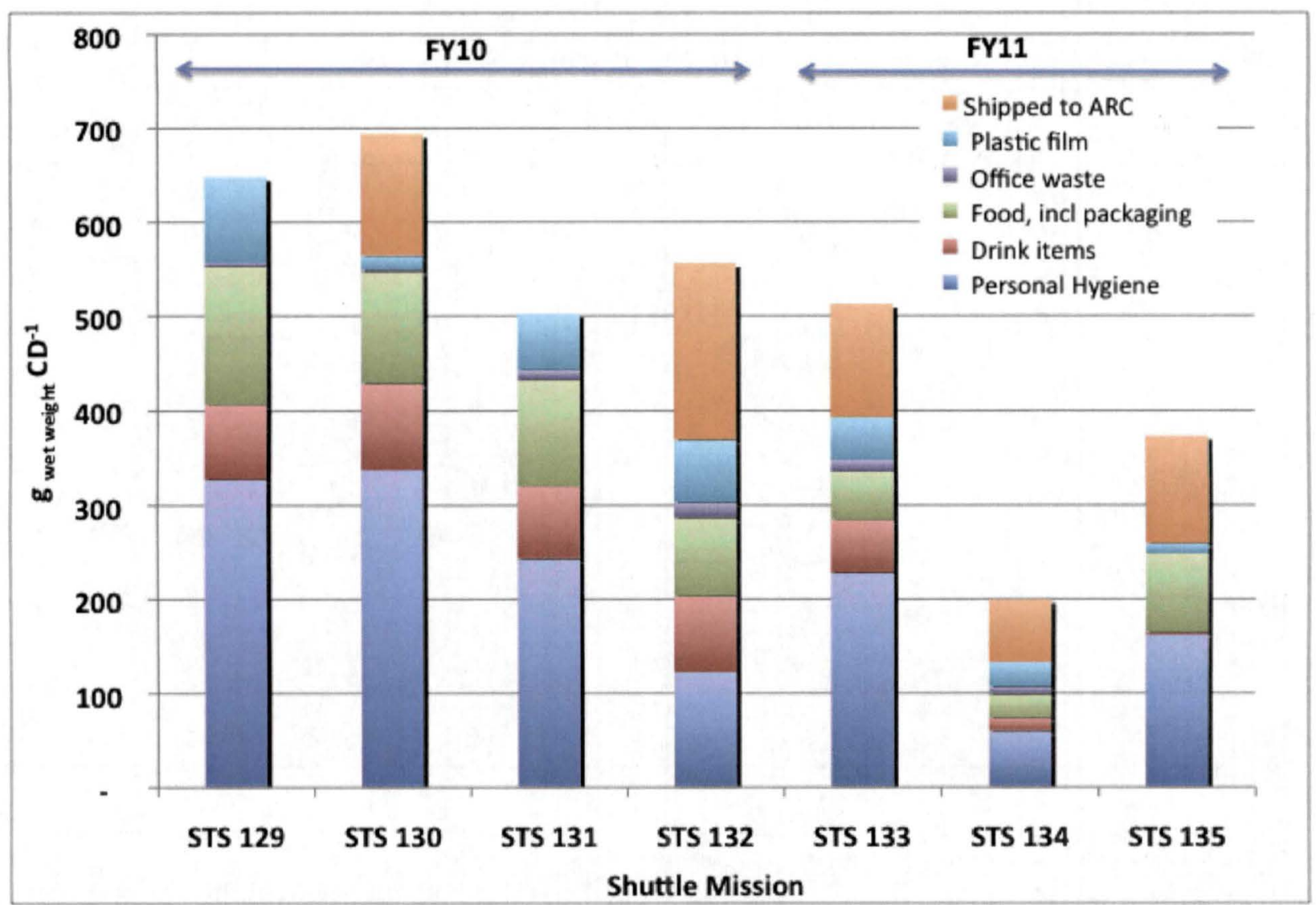

Figure 1. Trash production rate by STS mission for which wastes were received for FY10 and FY11. Stack components are by waste category within each mission.

Personal Hygiene Waste. Table 3 and FY10 results have shown that this waste category contains about half of the total wet trash. Except for STS 132, which is relatively lower, personal hygiene production rates follow the total rates shown in Figure 1. The rate of production for STS 134 seemed too low, and a perusal of the raw data showed that only 5 MAGs were returned and only 6 Elbow packs. This mission had 4 EVAs with two crew on each one, so 8 MAGs were expected. In other STS mission trash one Elbow pack per day of mission had been found, so for this 16 day mission 16 Elbow packs were expected instead of the 6 that were in the trash. These missing items, usually found in the Volume F compartment trash and not in the additional zip lock bags, may have been put into the ISS trash.

Drink Containers. The production rate for this category were fairly consistent until the last two missions, which again leads one to believe that trash was either left on the ISS or not included in the material received from the postlanding STS material stowage area. As drink containers can contain a significant amount of water that could be recovered, the waste data for these last two missions should not be used to estimate recoverable water.

Food Wastes and Packaging. The production rates for this category were trending downward from STS 129 to STS 134. The significance of this trend, if any, are not known. Overall, food wastes and packaging are produced at the second highest rate behind personal hygiene wastes.

Office Waste. As crew production rates for this waste category are nearly $1 / 10^{\text {th }}$ of the others, it has less importance. Unless soaked in water from food, drinks or personal hygiene wastes, it doesn't contain recoverable water. The production rates are quite variable over the 7 missions and none was found on the last mission, STS 135. 

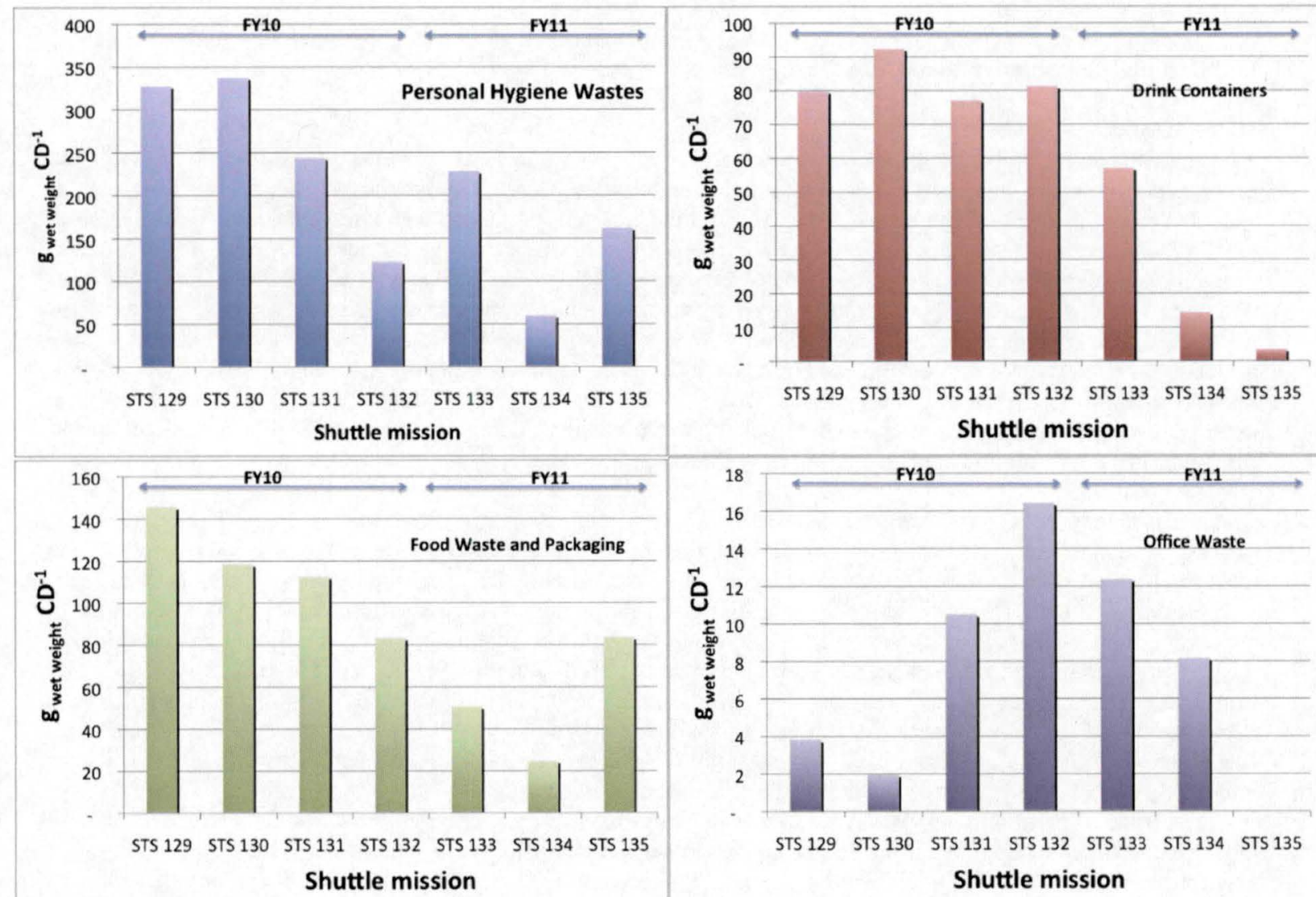

STS 129 STS 130 STS 131 STS 132 STS 133 STS 134 STS 135

Shuttle mission
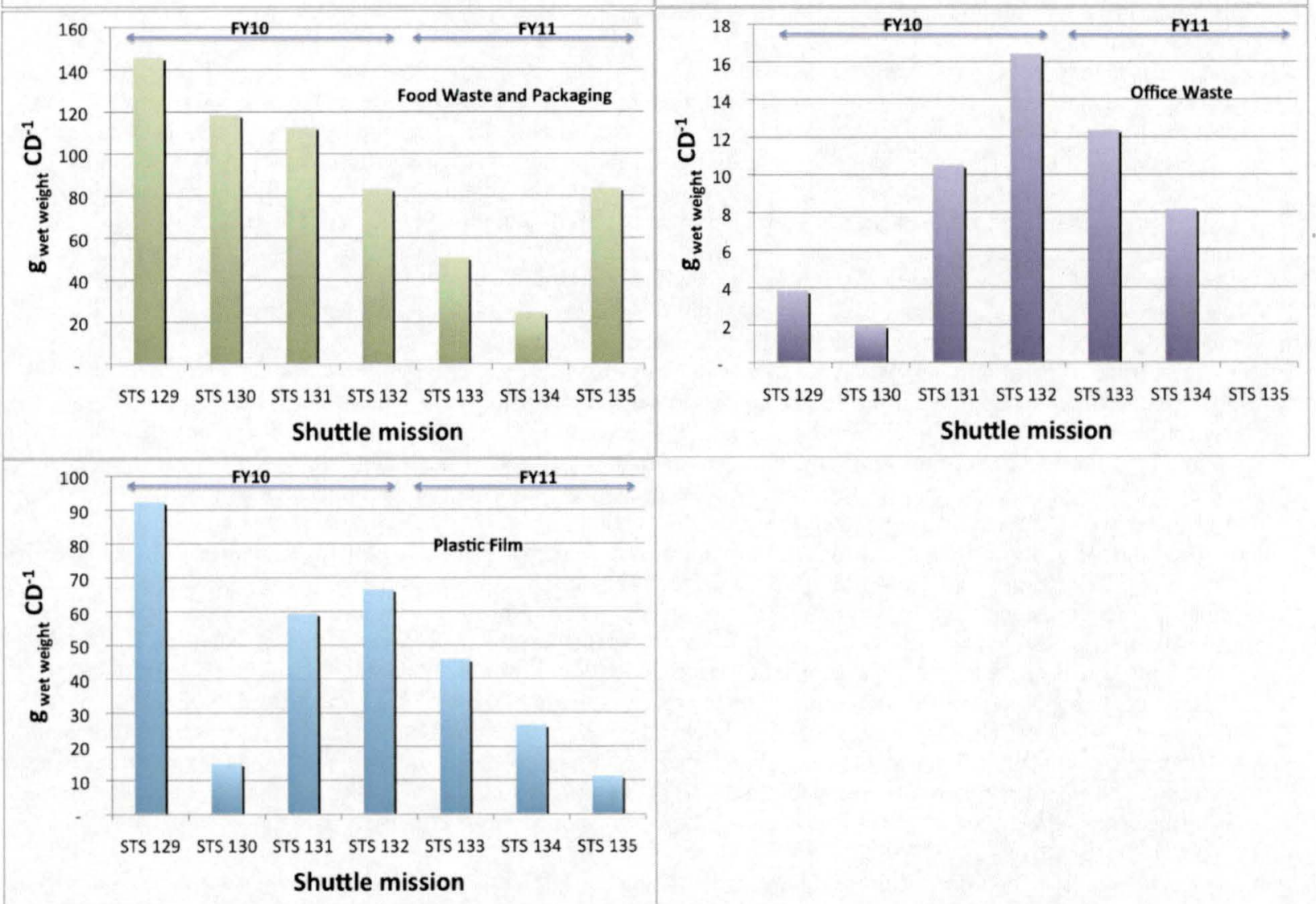

Figure 2.Trash production rates for each category of waste for the 7 STS missions that were part of the trash characterization project for FY10 and FY11. CD is crew day and is calculated by multiplying the number of crew members times the mission duration for each mission.

Plastic Film. The production rate for this category is of interest to Heat Melt Compaction technologies ${ }^{4}$, which are melting the plastic while compressing it into dense disks of probably sterile waste. STS 130 and, possibly, STS 135 had the lowest rates of production of this category. However, this category only contains waste packaging material that was used to enclose individual trash bundles ('footballs') and the Volume F bag itself, and does not include plastic film packaging for individual food and drink waste items. 


\section{B. Microbial characterization of STS trash}

\section{Overall Approach}

The Volume F compartment wet trash includes mealtime wastes such as leftover food and drink and the associated food packaging, personal hygiene articles, toilet wipes (termed "elbow packs" because of their shape), and Maximum Absorbancy Garment (MAG) worn by the crew during launch and extravehicular activities (EVA). For FY11, microbial characterization was conducted for three of these trash categories -- personal hygiene waste, drink containers, and food wastes plus food packaging. In addition, the surfaces of containment bags were also sampled for microorganisms. Not included were items that wouldn't support much microbial growth, such as office wastes and plastic film, and the Elbow packs and MAGs. In FY10 we found, as would be expected, that Elbow packs contained fecal microflora. These analyses were not repeated in FY11. With regard to the MAGs, we found in FY 10 that additional water absorbent capacity was such that all of the sterile diluent that we added to help in the extraction of MAG associated microbes was being absorbed. After adding several liters of diluent and getting no free water to sample, microbial characterization of these was abandoned.

\section{Surfaces of trash containment packaging}

If space trash were to be stored for long periods, then opened in the future by the crew for whatever reason, the most likely microflora they would encounter would be on the surfaces of the trash packaging. Thus, these surfaces were sampled as the STS trash bags were opened during the waste cataloguing and categorization at the start of processing. A variety of surfaces were sampled using sterile sampling sponges (Biotrace International, www.biotrace.com) that had been wetted with phosphate buffered saline (PBS). A sterile metal template was used to measure four separate $25 \mathrm{~cm}^{2}$ areas per item. The sampling sponges were then placed into sterile sample bags. When these were processed for microbial characterization the next day, $50 \mathrm{~mL}$ of sterile PBS was added to each bag. Bags were shaken vigorously by hand for two minutes before plating the diluted sample on agar media. Direct microbial counts were also performed on the diluted, shaken samples.

The results of the microbial characterization of surfaces of STS trash packaging are shown in Fig. 3. For these three charts, the X-axis shows, from left to right, the surface sampled as the trash bags were opened. Thus, the exterior of the Volume $\mathrm{F}$ and additional bags $\mathrm{A}$ and $\mathrm{B}$, if present, are listed first on the left, then, moving right, are the interiors of these bags followed by the exteriors of randomly selected trash bundles, coded FB for 'footballs', ending with the exterior and interior surfaces of Elbow packs. Also shown on these graphs, in callout boxes, are the identities of the microbes that grew on the agar plate count media.

The number of surfaces sampled for each mission and the number that were positive for cultivatable microbes were: STS 133, 11 surfaces, 4 positive; STS 134, 5 surfaces, all 5 positive; and STS 135, 5 surfaces, 0 positive. Although very low counts are shown on each graph in Fig. 3 for all missions, these low numbers are actually the lower detection limit, which means that no growth was observed on the plate count media. A count of zero is not plotted for these because a less dilute sample or a concentrated sample might have shown growth. (Plus, zero cannot be plotted on a $\log$ scale). When present, cultivatable counts were low: ca. $1 \times 10^{2} \mathrm{cfu} \mathrm{cm}^{-2}$ for STS 133 and $1 \times 10^{3}$ cfu $\mathrm{cm}^{-2}$ for STS 134. The direct count method showed that a variety of microbes on each surface were at or near 1 $\times 10^{6} \mathrm{cfu} \mathrm{cm}^{-2}$. This difference between direct counts and cultivatable counts is a common occurrence in environmental samples. By comparison with the FY10 study of 4 STS missions, the counts of cultivatable microbes on surfaces ranged between $\sim 1 \times 10^{1}$ and $\sim 1 \times 10^{4} \mathrm{cfu} \mathrm{cm}^{-2}$. And the direct counts were in the same range as FT11 counts at $1 \times 10^{6} \mathrm{cfu} \mathrm{cm}^{-2}$.

The identities of microbes from the plate count media for STS 133 and 134 trash bag surfaces were mostly aerobic bacteria (heterotrophs) and yeasts and molds. Among bacteria, notable were several of the genus Bacillus, which, as a spore-former, is resistant to heat and desiccation and could survive for long periods; and Ralstonia pickettii, which was present on all surfaces sampled for STS 134. Yeasts + molds identified were in the genera Rhodotorula, Candida, and Cryptococcus.

\section{Microbial Characterization of Trash Content According to Trash Category.}

As with the FY10 project, the trash was divided into different categories to examine the differences in microbial content for each different type. The categories of microbiological interest were: personal hygiene wastes (Fig. 4), drink pouches, i.e., containers (Fig. 5), and food wastes and food packaging (Fig. 6). As with the surface samples, if no counts were obtained with a particular medium, then those results are plotted as the minimum detectable limit for that category.

10

American Institute of Aeronautics and Astronautics 


\section{Surface Samples}

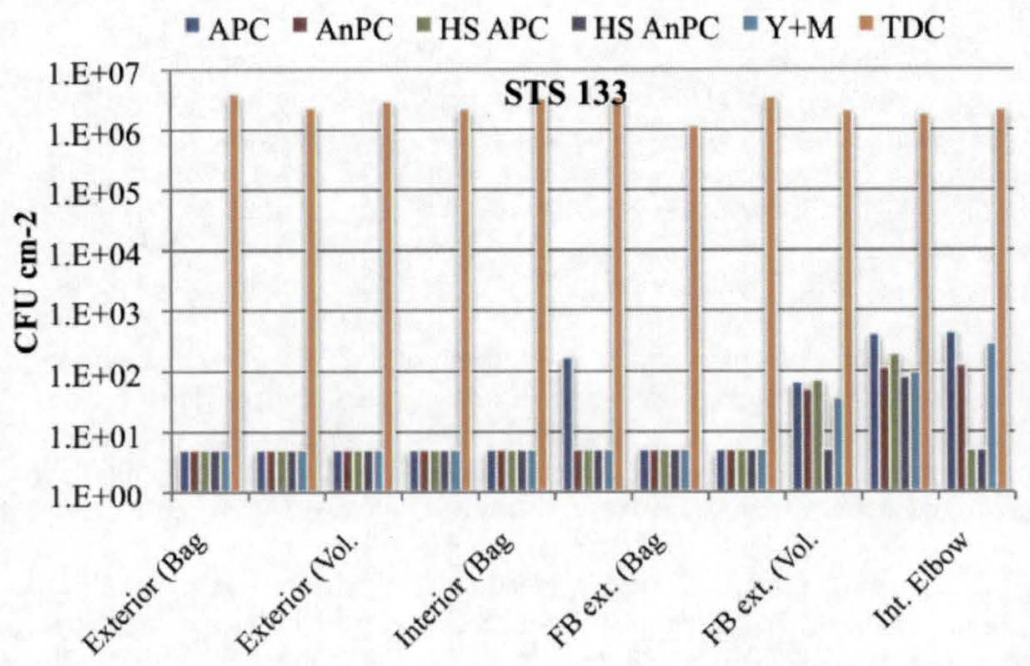

\section{Int. Vol. F: Nocardiodes simplex}

Bacteria Auquabacterium commune Janthinobacterium lividum Brucella melitensis FB ext.(Vol F): Bacillus thurigiensis Int. elbow pack: Bacillus cereus, Pseudomonas mendocina

\section{Yeast}

FB ext.(Vol F): Rhodosporidium diobovatum, Candida albicans, Cryptococcus laurentii

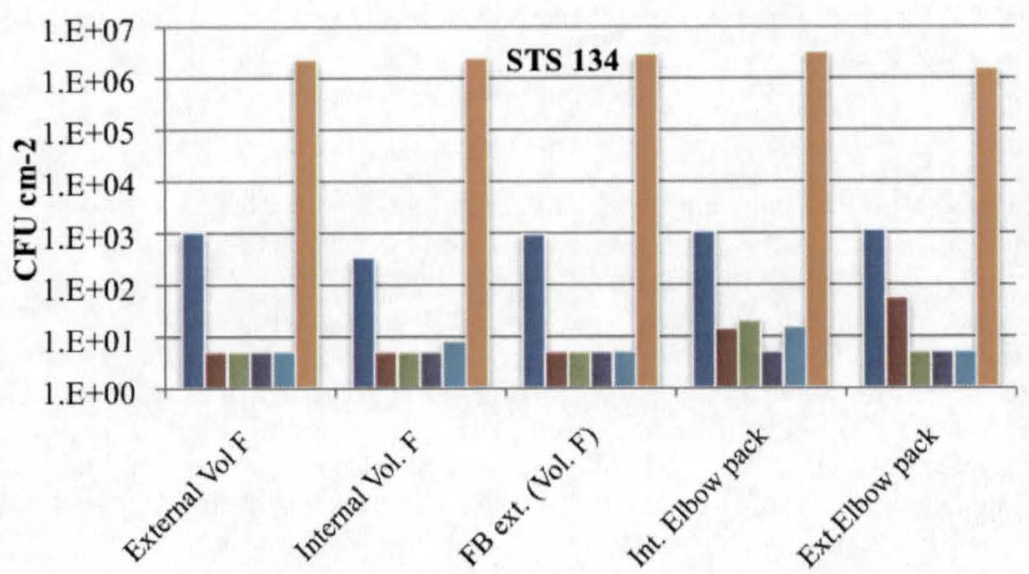

\section{Bacteria}

All sites: Ralstonia pickettii Ext. Vol.F: Variovorax paradoxus FB ext.(Vol F):Herbaspirillium Ex. elbow pack Staphylococcus haemolyticus, Enterobacter aerogenes

\section{Yeast}

Int. Vol. F and elbow pack Rhodotorula mucilaginosa

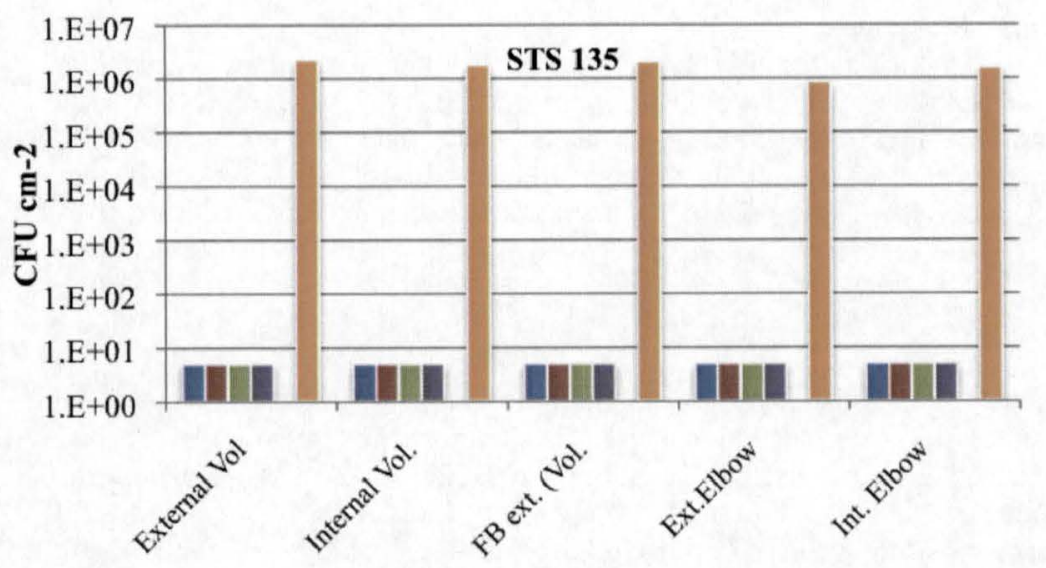

No Isolates recovered

Figure 3. Bar graphs of the number of microorganisms found on the internal and external surfaces of plastic-film bags in the trash of three STS missions. Shown are direct counts (Acridine Orange fluorescent stain direct counts) and cultivatable counts of a variety of physiological types. Organisms isolated are listed on the right of each graph. Legend: APC-aerobic plate count, AnPC-Anaerobic plate count, HS APC-heat-shocked aerobic plate counts, HS AnPC-heatshocked anaerobic plate counts, $\mathrm{Y}+\mathrm{M}$ - yeasts and molds, TDC - total direct counts. 


\section{Personal hygiene wastes (Fig. 4)}

The category of personal hygiene included wipes, meal napkins, etc. that were found in the waste and that didn't clearly belong to drink pouches or food waste. Although the MAGs and Elbow packs could be included in this category, we were not able to obtain adequate samples from the MAGS because these items had excessive diluent (sterile water) absorbant capacity. The Elbow packs were clearly toilet wastes and the several that were sampled early in the FY10 study did not yield very high counts. Both MAGs and Elbow packs were contained in separate, duct-tape wrapped football packages to keep the contents well isolated from the other trash. As the likelihood that these footballs would ever be knowingly opened would be low, attention in FY11 was focused on the other waste categories.

As with the other trash, personal hygiene wastes also contained aerobic heterotrophs (APC) and yeast and molds $(\mathrm{Y}+\mathrm{M})$ except for STS 135 Volume F contents, which had undetectable levels of yeast and molds (Fig. 4). Cultivatable counts ranged from $1 \times 10^{5}$ up to $5 \times 10^{8} \mathrm{cfu}^{-1}$ for the aerobes. Half of the aerobic heterotroph counts - i.e., for STS 133 Volume F and STS 134 Bag A,B,C and Volume F - were as high as the total counts. In addition, Bag A for STS 133 had significant counts of anaerobic heterotrophs (AnPC). Direct counts were high and ranged between $1 \times 10^{7}$ to $1 \times 10^{8} \mathrm{cfu} \mathrm{g}^{-1}$.

The identities of microbes isolated for all three shuttle missions were aerobic or facultative anaerobic bacteria (heterotrophs). All of these were isolated from aerobically incubated plate count media. Two identities of concern were the pathogens: Staphylococcus aureus from Bag B on STS 133 and Escherichia coli from the Volume F compartment personal hygiene waste on STS 134. Yeasts and molds identified included Candida albicans, Cryptococcus laurentii, and Rhodotorula mucilaginosa.

\section{Drink containers (Fig. 5)}

The category of drink containers included plastic-film laminated, metal foil drink pouches that had labels such as: drinking water, coffee, apple juice, fruit punch, etc. Pouch contents were consumed by crew members through a plastic port that held an insertable straw, which was frequently found still attached to the port. The pouches were cut open with a sanitized scissors in order to access the interior contents. This was done just prior to adding diluent to the drink containers before mixing by hand for 2 minutes.

The microbial characterization results for drink containers are shown in Fig. 5. High levels of cultivatable aerobic heterotrophs (APC), ranging from $\sim 1 \times 10^{6}$ to $\sim 1 \times 10^{7} \mathrm{cfu}^{-1}$ were seen in all samples from all three missions. For 4 of 6 samples the APC counts were as high as the direct counts for that sample and for the other 2 the APC counts were about an order of magnitude lower. The next highest cultivatable counts were for the yeast and molds $(Y+M)$, which were greater than 1 order of magnitude lower than the cultivable aerobic heterotroph counts. In general, other physiological groups and spore-forming bacteria (labeled HS for heat-shock) were above the minimum detection levels for all drink container samples.

The identities of microbes isolated from drink containers were predominantly aerobic heterorophs, i.e., Bacillus thuringiensis, B. amyloliquifaciens, Curtobacterium albidium, Leuconostoc citrium, Ralstonia pickettii, and Sphingomonas sanguinis. All of these were isolated from aerobically incubated plate count media. One identity of concern was the pathogen Staphylococcus aureus from the Volume F compartment on STS 135. Yeasts and molds identified included Rhodotorula glutinis and Torulospora glutosa. One anaerobic bacterium was identified from Volume F drink containers on STS 134.

\section{Food wastes, including food containers (Fig. 6)}

Because our past projects had examined the fate, including growth and proliferation of microbes on simulated space mission food wastes, our greatest interest in characterization of STS trash was the food wastes. Fig. 6 shows the numbers of microbes, both cultivatable and direct counts, in the food trash of the three STS missions. In general, the direct counts were an order of magnitude greater than the aerobic plate counts except in the Volume $\mathrm{F}$ bags for STS 133 and 134, where the two numbers were nearly equal. The range of direct counts were high, $\sim 10^{8} \mathrm{cfu} \mathrm{g}^{-1}$, for Volume F food wastes in STS 133 and 135 and closer to $\sim 10^{7} \mathrm{cfu} \mathrm{g}^{-1}$ for STS 134 volume F and Bag A.

For the cultivatable plate counts, aerobic, heterotrophic plate counts (APC) were present in all missions and all trash bags A $-\mathrm{F}$, but yeasts and molds were below detection limits in food wastes in Volume F bags for both STS 134 and 135. Anaerobic heterotrophs were found in Bag B and Volume F food wastes from STS 133. 
Personal Hygiene Waste

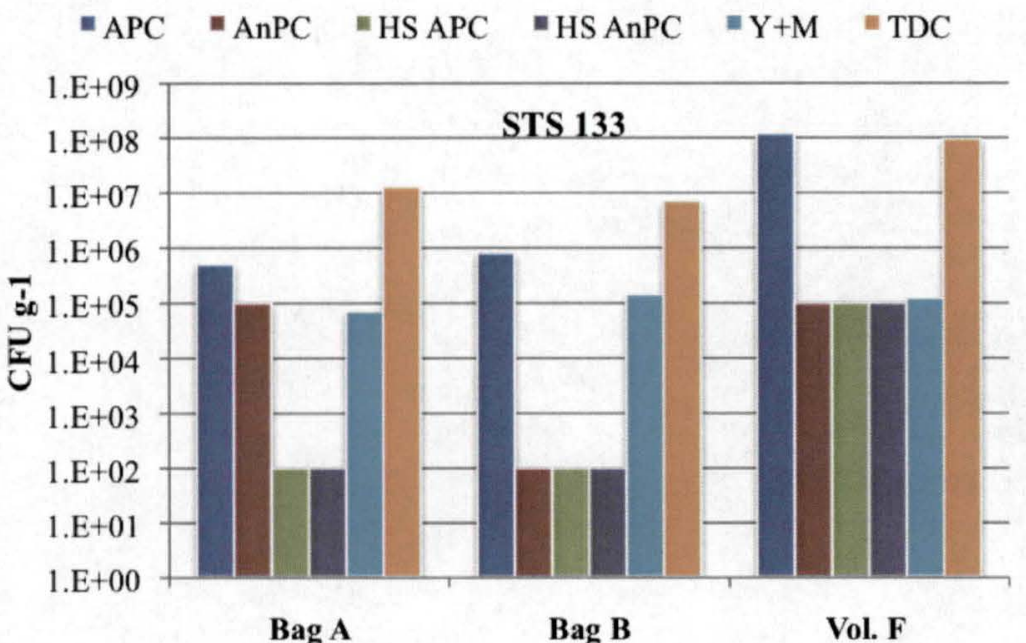

\author{
Bacteria \\ Bag B: Serratia ficarra \\ S. aureus \\ Vol. F. Lecleria adecarboxylata, \\ Enterococcus faecalis \\ Fungi \\ Bag A: Candida albicans, \\ Bag B: $R$. diobovatum, \\ Cryptococcus laurentii
}

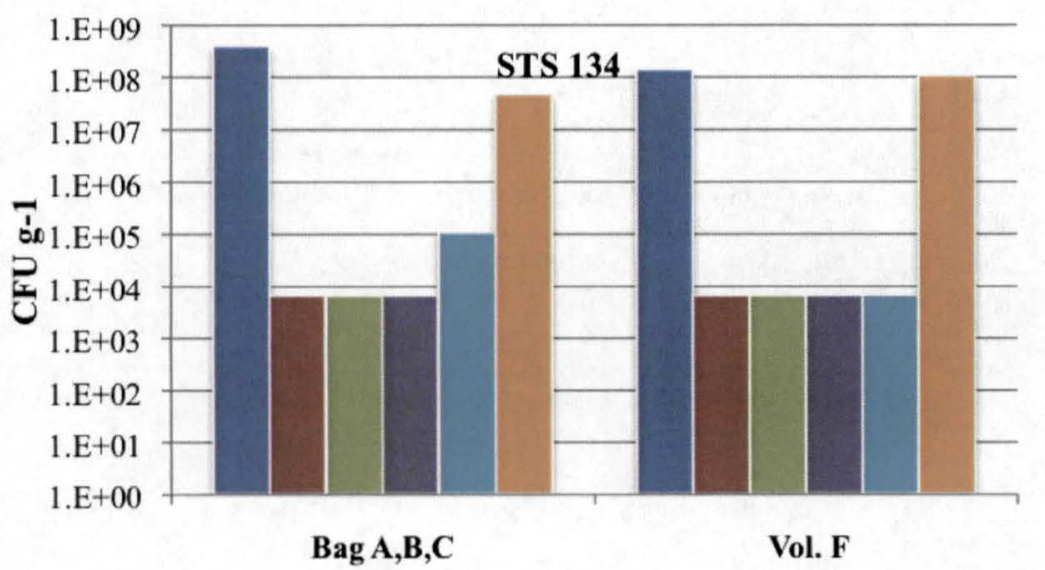

\title{
Bacteria
}

Bag A,B,C: Citrobacter koseri

Vol. F: Curtobacterium luteum,

E. coli, Leuconostoc citreum

$$
\text { Fungi }
$$

Vol. F: Rhodotorula

mucilaginosa

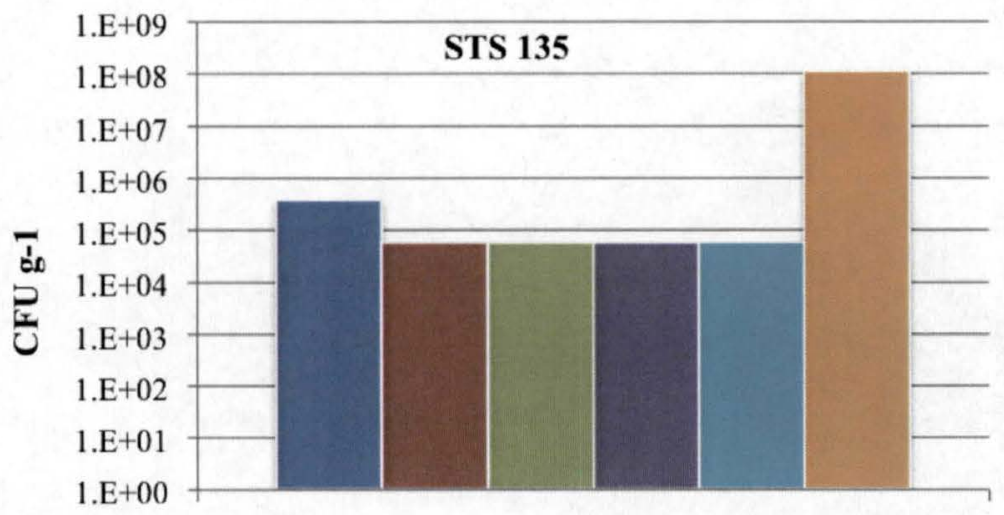

Vol. F

Bacillus. amyloliquifaciens

Figure 4. Bar graphs of the number of microorganisms found in personal hygiene wastes in the trash of three STS missions. Shown are direct counts and cultivatable counts of a variety of physiological types. Organisms isolated are listed on the right of each graph. Legend: APC-aerobic plate count, AnPC-Anaerobic plate count, HS APC-heatshocked aerobic plate counts, HS AnPC-heat-shocked anaerobic plate counts, $\mathrm{Y}+\mathrm{M}$ - yeasts and molds, TDC - total direct counts. 

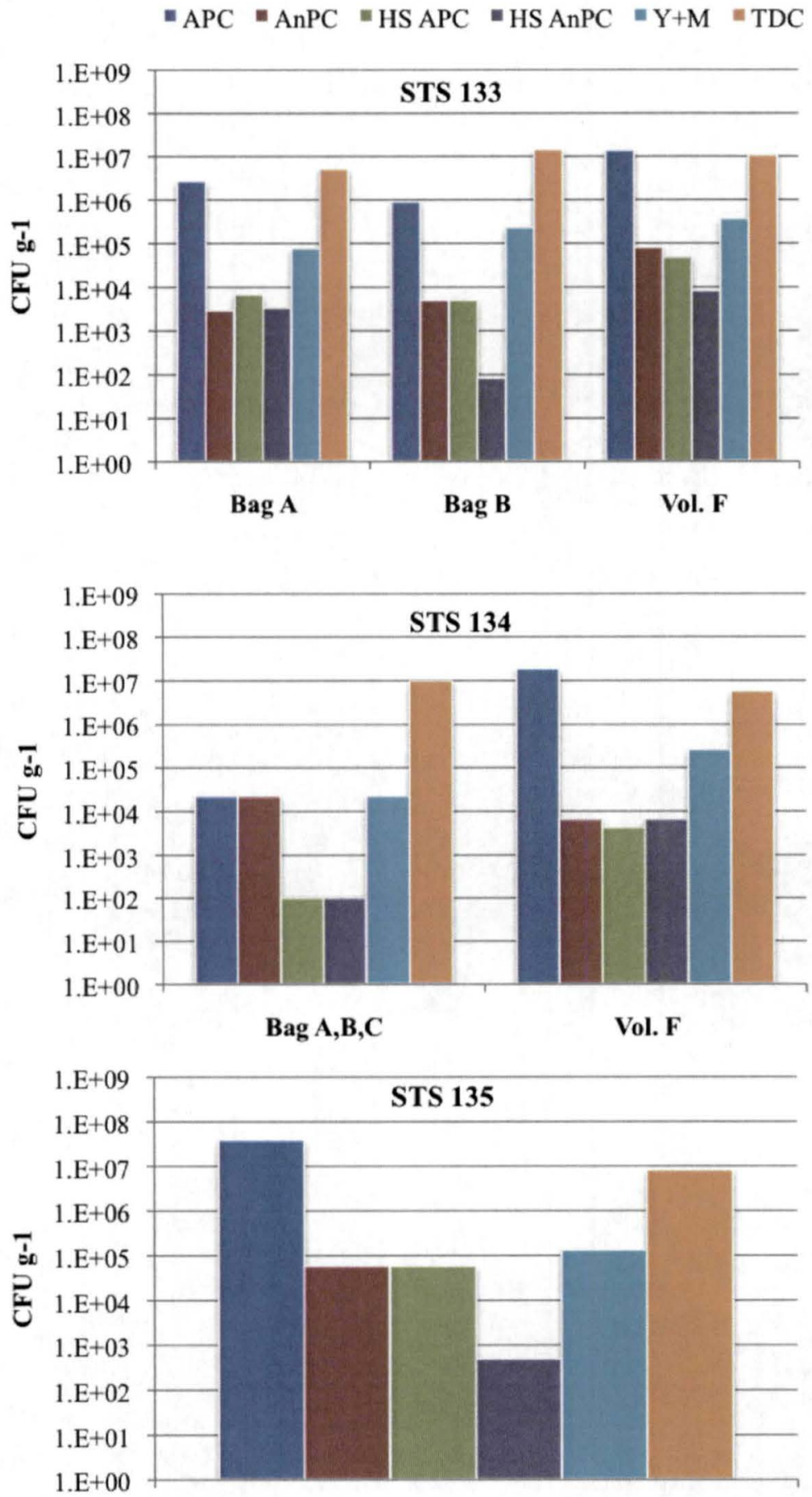

Vol. F

\section{Bacteria}

Bag A: Curtobacterium albidium

Bag B: Bacillus thuringiensis Vol. F. B. amyloliquefaciens

Klebsiella pneumonia

Leuconostoc citrium

Curtobacterium albidum

\section{Bacteria}

Bag A,B,C: Ralstonia pickettii, Sphingomonas sanguinis

Vol. F: Enterobacter aerogenes, Bacillus sp,

Leclercia adecarboxylata

Camplyobacter/Clostridium

\section{Bacteria}

S. aureus ssp aureus, S. pasteuri Yeast

Rhodotorula glutinis, Torulospora globosa

Figure 5. Bar graphs of the number of microorganisms found in drink containers in the trash of three STS missions. Shown are direct counts and cultivatable counts of a variety of physiological types. Organisms isolated are listed on the right of each graph. Legend: APC-aerobic plate count, AnPC-Anaerobic plate count, HS APC-heat-shocked aerobic plate counts, HS AnPC-heat-shocked anaerobic plate counts, $\quad \mathrm{Y}+\mathrm{M}$-yeasts and molds, TDC - total direct counts.

American Institute of Aeronautics and Astronautics 

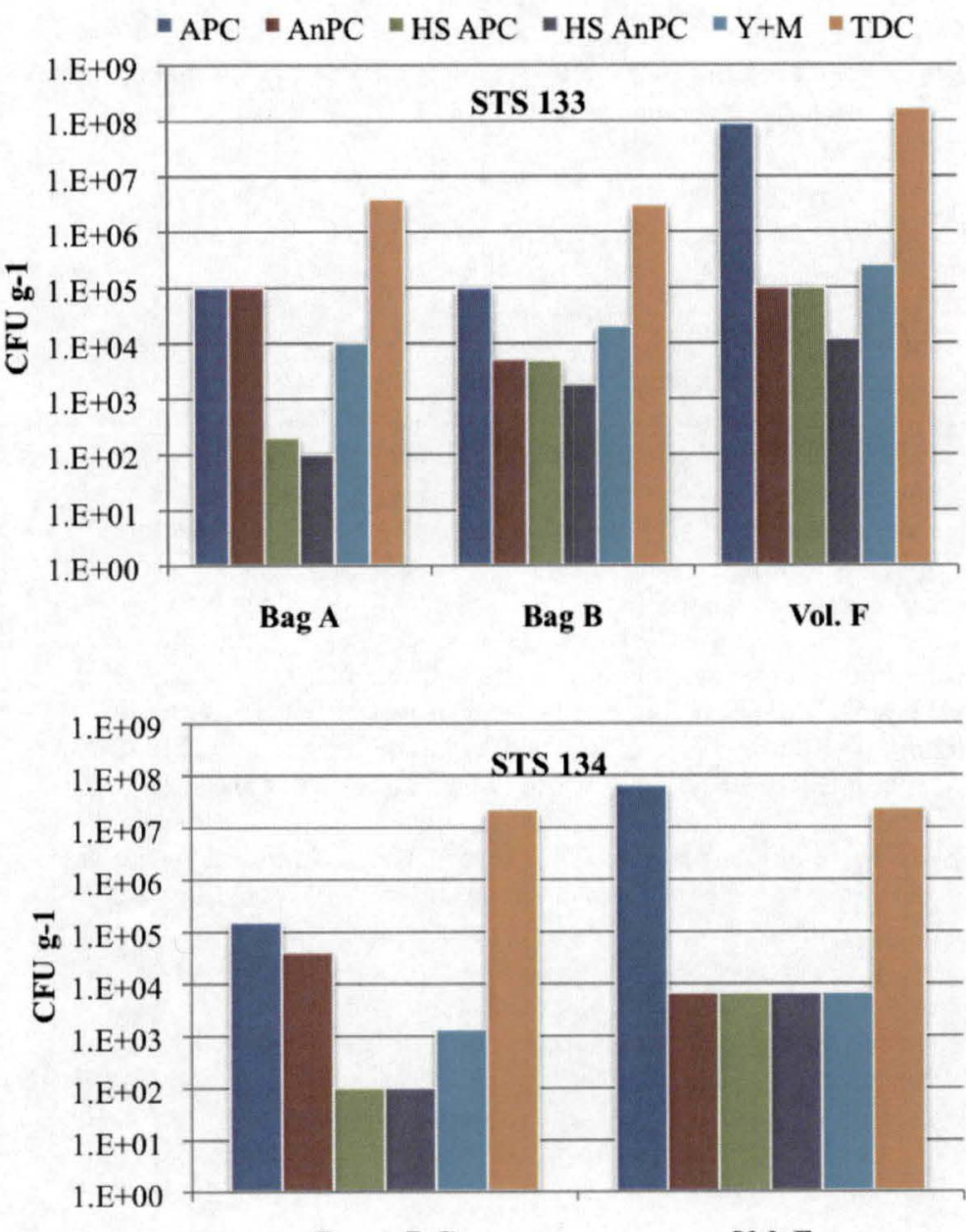

Bag A,B,C

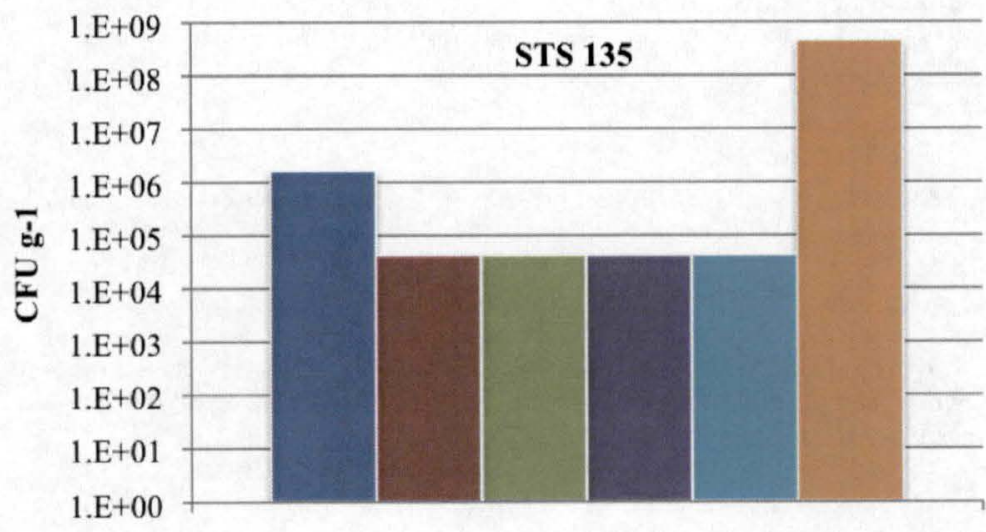

Vol. F

\section{Bacteria}

Vol. F. Bacillus amyloiquefaciens, Curtobacterium albidum, Leuconostoc mesenteroides

\section{Bacteria}

Bag A,B,C: S. epidermidis,

$S$. pasterui, E. coli

Vol. F: Staphylococcus

epidermidis, Bacillus subtilis,

Sphingomonas terrae

Fungi

Vol. F: Penicillium sp.

\section{Bacteria}

S. aureus

Figure 6. Bar graphs of the number of microorganisms found in the food wastes including packaging in the trash of three STS missions. Shown are direct counts and cultivatable counts of a variety of physiological types. Organisms isolated are listed on the right of each graph. Legend: APC-aerobic plate count, AnPC-Anaerobic plate count, HS APC-heat-shocked aerobic plate counts, HS AnPC-heat-shocked anaerobic plate counts, $\mathrm{Y}+\mathrm{M}$ - yeasts and molds, TDC - total direct counts.

15

American Institute of Aeronautics and Astronautics 
As with the other waste categories in FY11 samples, the food waste isolates were predominantly aerobic heterotrophs commonly found in earth-bound environmental samples. Several isolates were identified as pathogenic bacteria including Staphylococcus aureus (STS 135 Volume F bag) and E. coli (STS 134 Bag A,B,C).

\section{Conclusion}

The composition of trash returned from the three recent, and last, STS missions - STS 133, 134, and 135 - was determined. The trash material was 'Volume F' trash and other trash contained in large zip-lock bags that accompanied the Volume $\mathrm{F}$ trash. This report covers trash content, weight and water content and the microbial characterization of this trash. STS trash was usually made available within 2 days of landing at KSC. The trash was weighed and the contents were cataloged and placed into one of the following categories: personal hygiene items including EVA maximum absorbent garments (MAGs) and Elbow packs (daily toilet wipes, etc), drink containers, food waste (and containers), office waste (paper), and packaging materials - plastic film and duct tape. The average trash generation rate for the three STS missions: Total wet trash was $0.362 \pm 0.157 \mathrm{~kg}_{\text {wet }} \mathrm{crew}^{-1} \mathrm{~d}^{-1}$. This was considerably lower and more variable than the average rate for 4 STS missions reported for FY $10^{1}$. Cataloging by category: personal hygiene wastes accounted for $56 \%$ of the total trash; drink items were $11 \%$ of total weight; food wastes were $18 \%$ of total weight; office waste and plastic film were $3 \%$ and $12 \%$ of the total waste, respectively.

STS trash wastes have an abundance of easily biodegraded compounds that can support the growth of microorganisms. The research presented here shows that large numbers of bacteria and fungi have taken advantage of this readily available nutrient source to proliferate. Exterior and interior surfaces of plastic film bags containing trash were sampled and counts of cultivatable microbes were generally low and mostly occurred on trash bundles within the exterior trash bags - Volume F compartment and additional waste containing zip-lock bags. Personal hygiene wastes, drink containers and food wastes and packaging all contained high levels of mostly aerobic heterotrophic bacteria and lower levels of yeasts and molds. Isolates from plate count media were obtained and identified and proved to mostly be aerobic heterotrophs with some facultative anaerobes. These are usually considered common environmental isolates on Earth. However, several pathogens were also isolated: Staphylococcus aureus and Escherichia coli.

If storage of space-generated trash / wastes is the only 'treatment' option, then, to prevent crew exposure to dangerous levels of cross-contaminating pathogens, we recommend that food wastes be placed immediately into storage and the containers immediately sealed. We believe that a better treatment option would be to limit microbial growth through immediate dehydration of food, or other, wastes or immediate sterilization of these wastes. The results reported here can be used to determine requirements and criteria for NASA Waste Management Systems and . These methods and resulting data will provide a basis for testing technologies for the ability to limit contaminant survival, growth and proliferation.

\section{Acknowledgments}

The research reported in this paper was supported by NASA Life Support and Habitation Systems (currently named Next Generation Life Support) project through the Waste Management System element. Thanks to Michele Birmele, John Catechis, Griffin Lunn, and Timothy Haire for technical support.

\section{References}

${ }^{1}$ Strayer, R. F., Richards, J., Hummerick, M. P., Sager, J. C., "Microbial Characterization of Compacted vs. Non-compacted simulated Orion Crew Vehicle Food Trash Compartment Waste," SAE Tech. Rep. 2007-01-3268, 2007.

${ }^{2}$ Strayer, R., Hummerick, M. E., Richards, J. T., McCoy, L. E., Wheeler, R. L., "Characterization of Volume F trash from four recent STS missions: weights, categorization, water content," 41st International Conference on Environmental Systems (ICES), 2011, American Insttitute for Aeronautics and Astronautics, AIAA-2011-5126.

${ }^{3}$ Strayer, R., Hummerick, M. E., Richards, J. T., McCoy, L. E., Wheeler, R. L., "Characterization of Volume F trash from four recent STS missions: microbial occurrence, numbers, and identifications," 41st International Conference on Environmental Systems (ICES), 2011, American Insttitute for Aeronautics and Astronautics, AIAA-2011-5127.

${ }^{4}$ Kish, A. L., Hummerick, M. P., Roberts, M. S., Garland, J. L., Maxwell, S., and Mills., A., "Biostability and Microbiological Analysis of Shuttle Crew Refiuse," 32nd International Conference on Environmental Systems (ICES)., 2002. Society for Automative Engineers, Inc., 02ICES-113.

${ }^{5}$ Peterson, B. V., Hummerick, M., Roberts, M. S., Krumins, V., Kish, A. L., Garland, J. L., Maxwell, S., and Mills, A., "Characterization of Microbial and Chemical Composition of Shuttle Wet Waste with Permanent Gas and Volative Orgnaic Compound Analyses," Adv. Space Res., Vol. 34, pp. 1470-1476, 2004

${ }^{6}$ Pace, G.S., and Fisher, J., "Testing and Analysis of the First Plastic Melt Waste Compactor Prototype," SAE Tech Rep. 2005-01-3080, 2005 